\section{About-turn on} \section{regulations}

Washington

IN response to thousands of complaints about its original proposals to regulate the welfare of laboratory animals, the US Department of Agriculture has made a dramatic about-turn in its approach to the issue, conceding that research institutions should themselves decide how to meet the required standards.

But animal welfare groups are angry that almost four years after Congress passed the legislation requiring the new regulations, the result is 'performance-based' standards which will be difficult to enforce and, they say, may not improve the welfare of laboratory animals.

Parts one and two of the new regulations, developed by the Animal and Plant Health Inspectorate Service (APHIS), were published in their final form last week. Significant revisions from the original plans bring the regulations closely in line with the current Public Health Service guidelines. Dale Schwindeman of APHIS says that institutions already following those guidelines will have to make few changes to meet the new regulations.

The third and most controversial part of the regulations, which includes the standards for cage sizes, exercise for dogs and means for creating environments for primates in order to improve their 'psychological well-being', is being drastically revised in response to the 18,000 comments received since it was first published in March. Schwindeman says the final rule will not be ready before the end of the year.

Animal-welfare groups have won some small victories. The institutional committees which will monitor compliance with the regulations, with the power to suspend research immediately, must include one member of the public and to investigate complaints from the public. That the regulations acknowledge public opinion at all is "fantastic", says Bob Cotreau of the Animal Welfare Institute. $\mathrm{He}$ also applauds the fact that the regulations define pain according to human standards.

Despite strong opposition from researchers, APHIS insists that inspectors should have full access to research facilities with authority to take photographs and photocopy relevant documents.

It argues that the inspections would not disrupt research, and that documents would not be available to the public. Neither did researchers succeed in persuading APHIS that disclosing the location of facilities where animals are housed would create security problems.

APHIS originally estimated the costs of implementing the regulations to be about $\$ 900,000$ million, but the ultimate cost will depend on the final form the standards take when they are published next year.

Christine McGourty

\title{
Abortion issue destroys board
}

\section{Washington}

THE US Congressional Bioethics Board seems certain to be dissolved next month after four years in which it has made no progress on any of its planned studies on controversial ethical issues in biomedical research and health care. The board has spent most of its time arguing over the selection of members of its advisory committee, with candidates' views on the abortion issue providing the litmus test for admission.

The board is a bipartisan group of 12 congressmen established to consider issues such as the withdrawal of nourishment from terminally ill patients, genetic engineering and fetal research.

The demise of the board is ensured by the action of its newest member, Senator Don Nickles. He has introduced an amendment to the bill that provides funds for the committee, blocking further expenditure until the board succeeds in selecting a chairman, vice-chairman and fills all vacancies on its advisory committee.

The Senate is likely to support the amendment when it votes on the bill in the next few weeks, making it impossible for the board to continue to function unless it can resolve its internal problems. That now seems virtually impossible.

Earlier this year, it seemed that the committee might finally be able to begin its first study, on genetic engineering, but the death of one member opened a new vacancy and all work was suspended.

One of the casualties of the board's inactivity is a decision on federal funding of fetal research, which rests on a report due from the advisory committee. At present only fetal research which is either therapeutic or within a strict 'minimal risk' standard can be carried out. That standard allows non-invasive procedures and blood tests but prohibits any new area of fetal research. Research that exceeds the minimal risk standard requires a waiver from the Department of Health and Human Services (DHHS). But in 1985 it was decided that waivers would not be issued until a report was received from the committee on their use.

Advocates of fetal research are divided over the existence of the Congressional Bioethics Board. "We wouldn't want it to be reauthorized if nothing is going to be done", said Sarah Carr, of the Association of American Medical Colleges (AAMC). "If you're opposed to fetal research then that's a good way to keep it from happening." Critics of the board say that the legislation that created the committee was designed in such a way that there would be a stalemate on everything.

The AAMC is urging the federal government to reconstitute a separate DHHS Ethics Advisory Board (EAB) whose charter expired in 1980. Advocates of fetal research were pleasantly surprised last year when the DHHS published a proposed charter for a new EAB (see Nature 334, 185; 1988), but no further action was taken and a final charter has not been published. The AAMC recently wrote to the assistant secretary for health. James Mason, saying that "the absence of a board since 1980 has inhibited progress in all research involving human in vitro fertilization as well as research on the prenatal trans-mission of AIDS and on new diagnostic imaging techniques".

John Fletcher, professor of biomedical ethics and religious studies at the University of Virginia said there are signs that the reformation of the $\mathrm{EAB}$ "is being taken very seriously".

"Reproductive biology in the federal sector of science is being suppressed by the absence of the EAB ... the US is way behind the United Kingdom in the study of the causes and treatment of infertility", he said.

The AAMC is also urging the Secretary for Health, Louis Sullivan, to lift a ban imposed last year on the use of fetal tissue in research. At that time the assistant secretary for health requested a report on the issue from the National Institutes of Health.

The report concluded that the use of aborted fetal tissue in research is acceptable provided strict safeguards are followed to prevent potential abuses (see Nature 339, 411; 4 June 1989). No action has been taken in response to the report, which now lies with Mason.

Christine McGourty

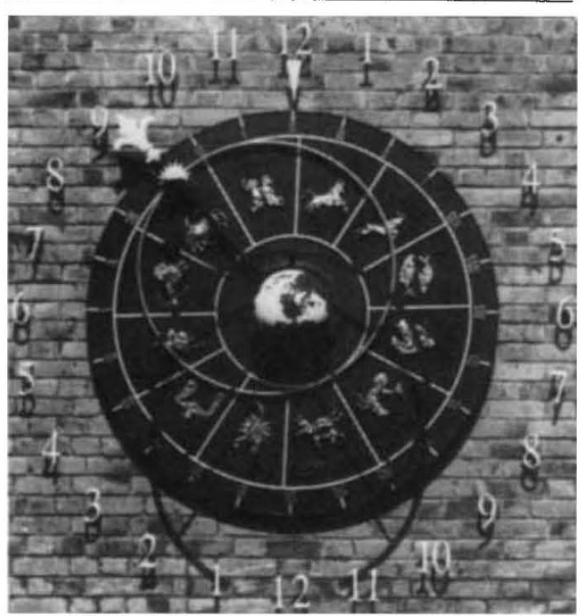

This 8-foot-diameter astronomical clock was installed this summer at Leicester University. The astrolabe projection shows 'clock' time as GMT (the white fleur-de-lis), as well as sidereal and solar time, relative positions of Earth, Sun, Moon and stars, phases of the Moon and rising and setting over the local horizon. The clock was designed and built by Alan Mills and Ralph Jefferson. 